\title{
Proceeding
}

6th INSHS International Christmas Sport Scientific Conference, 11-14 December 2011. International Network of Sport and Health Science. Szombathely, Hungary

\section{Role of motivation in artistic gymnastics by results of a questionnaire based international survey}

\author{
ISTVÁN MUNKÁCSI ${ }^{1} \triangleleft$, ZSUZSA KALMÁR ${ }^{1}$, PÁL HAMAR ${ }^{1}$, ZSOLT KATONA², HENRIETTE DANCS $^{3}$ \\ ${ }^{1}$ Faculty of Physical Education and Sports Sciences, Semmelweis University, Hungary \\ ${ }^{2}$ Faculty of Education, University of Szeged Gyula Juhász, Hungary \\ ${ }^{3}$ Faculty of Physical Education, Visual Arts and Music, University of West Hungary, Hungary
}

\begin{abstract}
Munkácsi I, Kalmár Z, Hamar P, Katona Z, Dancs H. Role of motivation in artistic gymnastics by results of a questionnaire based international survey. J. Hum. Sport Exerc. Vol. 7, No. Proc1, pp. S91-S102, 2012. The hardest part of coaching work is the psychological preparation of athletes and gymnasts, where the aim is to achieve higher performance. Motivation - as the driving force of our actions - has an increased role in preparing the gymnasts, as during trainings they have to solve more complicated, more difficult tasks than in their everyday lives. A strong motivational driving force is essential to perform the high level gymnastic exercises and to practice them daily. In our inquiry we wanted to find out how much the questioned 152 foreign gymnastics coaches find motivation important and improvable. It was also a question if it is necessary to develop motivation in order to reach new aims or if the genetic level that was brought along is enough. Our results show that it is necessary to develop and reinforce motivation continuously to reach higher performances. Use of educational methods have important roles in doing so, which help to determine the long term and short term main goals and sub-aims - as a motivation. Key words: COACHES OPINION, INTRINSIC AND EXTRINSIC MOTIVATION, EDUCATIONAL METHODS, OPINIONS OF GYMNASTIC COACHES.
\end{abstract}

\footnotetext{
Corresponding author. Semmelweis University, Faculty of Physical Education and Sports Sciences, Budapest, Alkotás u. 44. $\mathrm{H}-1123$.

E-mail: munkacsiistvan@freemail.hu 6th INSHS International Christmas Sport Scientific Conference, 11-14 December 2011. International Network of Sport and Health Science. Szombathely, Hungary JOURNAL OF HUMAN SPORT \& EXERCISE ISSN 1988-5202

(c) Faculty of Education. University of Alicante doi:10.4100/jhse.2012.7.Proc1.11
} 


\section{INTRODUCTION}

Motivation is a significant, basic element of human behaviour, which determines the smaller or greater dynamics of the actions (Khan, 2011). Certain challenges, incentives, motives are necessary to satisfy human needs. Attitude, needs, motives and other personal characteristics determine what we do and how we act (Nagy, 2001; Doil, 1980). To be motivated means that one feels like one needs to do something, one is under some kind of a pressure. The main question is what kind of action one proposes. There are huge differences among people's motivation levels (Ryan \& Deci, 2000).

When several motives appear at the same time, we have to decide which motivated action we perform. This decision can be affected, modified by many external and internal factors. To make the right decision one needs many positive attributes (Stuller, 1983). The quality of the aim, the possibility of accomplishment is conclusive during the coaching of any sport movement. When we teach any movement, there has to be a pre-formed, emotionally interlaced goal in the sportsperson, which can help the accomplishment (Simon et al., 2010). One of the most important motivating forces is the energy spent on caring for our health; however this is not always the case, as survey results prove it (Bognár et al., 2010).

One of the varied human aims, motivations, and goals could be for example, lifelong learning. These motivated aims depend on many external and internal factors (Hamar et al., 2011).

However this driving force often inspires the same person to behave differently in the same situation. According to Séra (1988) motivation is a generic term of psychology; it initiates action and individual behaviour in people and in animals. In any part of life goals are necessary to take further steps, to develop, to get better results. According to Rubinstein (1974) the motive can be considered as the source of action, its evoker. The colourful reasons originate from the person's interests, requirements and needs.

Motivation has an important role in the accomplishment of outstanding, extraordinary social activities. Motivation is behind outstanding achievements, which provides energy and moves the creative urge, the determination to do something, the enthusiasm and the strong will in persistence (Czeizel, 2004). Kozéki Béla (1980) believes that an individual's motivation is the result of one's bringing-up. Motivation itself is a significant task for teachers in schools and coaches during the daily training work to activate existing motivation, to strengthen and to develop it in the students or sportspeople (Lappints, 2002). It is very important to provide a creative atmosphere at the trainings, where coaches can bring to the surface the inner motivations, the motivational basis of sportspeople. This motivational basis has to be strengthened from outside by guiding from the coaches as the exercises become more and more difficult during trainings. It is easier to motivate the given sportsperson if the coach knows the students well (Crust, 2003).

Regarding the development of condition related abilities significant advancement can be seen in the elite sport of the world. Apart from this important factor of performances, Counsilman foretold in 1977 that sportspeople's - in his case swimmers' - successfulness is greatly dependant on the better psychical state, which can become effective at the trainings and mostly at competitions (Counsilman, 1977).

Extrinsic and intrinsic motivation

When the intrinsic motivation is present, someone is accomplishing an enjoyable, interesting action. Curiosity and the urge for discoveries are present in us from birth, which does not need external inspiration and it accompanies us through life. 
However, during movements driven by the extrinsic motivation, one has to comply with external requirements that help to reach the proposed goals. After childhood one has to accept rules (contrary to accomplishing the action driven by the internal intrinsic motivation), external forces start to control our lives and some kind of an external incentive or resource appears (Ryan \& Deci, 2000). The movement material of gymnastics is taught within a special pedagogical situation at a special site, in the gymnastic hall. In the case of the extrinsic motivation some kind of a touchable external object or the appraisal of another person is the main aim of the action, so the action becomes device-like (Szabó, 2004).

\section{Achievement motivation}

The achievement motivation is a kind of urge for the sportsperson to continuously raise the performance that has been achieved by him/her (Nagy, 2001). Biróné (2004) says that the role of achievement motivation is significant at the special site of the competitions. The sportsperson clearly aims to achieve a mental-moral value and aims to exceed his/her previous results. The performance motive - as a special driving force - has several functions, as it shows the human actions: choice, direction, intensity and persistence; also, competition has an outstanding role (Fodor, 2007). Nagykáldi (1998) says that there is a very strong link between performance motivation and competition. The aim is to reach better competition results. It is a special, distinctly human feature that one wants to stand out in one's immediate environment through behaviour and actions. One wants to achieve more than others to be acknowledged. Gymnastics as an aesthetical sport is especially suitable for raising performance motivation and the level of requirements. Szabó (2004) believes that the type of action that is driven by performance motivation corresponds with our own demands. If our own aims (e.g.: competition results) are successful, the requirement level is raised regarding the next task (competition). However, if the expected performance (result) does not occur, the level of requirement decreases regarding the next event. Serial successes can raise the level of requirement (Jacek, 1980; Szabó, 2004). This is a long pedagogical and psychological process. As we are talking about competitive sports, the competitors' main aim is the success (at trainings and at the competition). We also have to mention that the unrealistically high performance and requirement level is in connection with the anxiety of the competitor (Jacek, 1980; Nagykáldi, 1998). The more a coach knows the gymnasts, the stronger intrinsic motivation basis can be formed in them! Development of achievement motivation mustn't lack - especially in case of young gymnasts, taking into consideration the age characteristics - the sense of achievement that can be reached most effectively using expertly chosen pedagogical methods, and through appointing reachable aims.

Rókusfalvy (1981) thinks that performance requirement is closely connected as a main element to performance motivation. This is apparent as the sportsperson attempts to outperform his/her previous results or performances at trainings and at competitions too. Team sports - gymnastics is like that when there is a team competition - provide great opportunities to develop and reinforce social motivation. The competitor's sense of responsibility is extended regarding other team members, so s/he as a member of a team can help the fellow team members with the best possible individual performance.

Doil (1980) thinks that the performance requirement does not always elicit immediate motivation, in certain cases an unsatisfied state exists for a long time and the activity-accomplishment related intrinsic motivation only evolves later. Achievement motivation can be developed and reinforced, the family, the coach and the external "social-cultural effects" around the sportsperson play the main roles in it (Rókusfalvy, 1986). 
The coach helps the competitor to build up higher and higher requirement levels through adequate feedback evaluating the performance and the results. This greatly affects the immediate actions, the successful accomplishment of the elements and exercises. The importance of the power of motivation and the emotional level at the given moment is evident (Jacek, 1980).

Harasztosiné (2002) mentions performance motivation and requirement level together, however in different interpretations. According to her the difference between them is that the requirement level is a behaviour appearing in competitive situations and performance motivation is a pressure system that energizes this characteristic behaviour. The importance of performance motivation is enhanced by Khan's (2011) observation that inverse proportionality exists between the level of performance motivation and competition related anxiety. This statement can encourage coaches to try and develop bigger and bigger differences in favour of performance motivation against anxiety in the students during the training work. Réthy E. (2003) states that teachers have to identify and exploit the motives in the students, later they have to improve those to reach higher aims. Also, in order to acquire new knowledge (in our case it can be a new element, a part of an exercise or a whole exercise) such educational process has to be created and organized which makes it possible for the student (sportsperson) to be self-controlled and which raises the internal motivational level.

\section{Hypotheses}

$\mathrm{H} 1$ - We assume that the most important extrinsic motivation for the gymnasts to continue further trainings is the success reached at competitions.

$\mathrm{H} 2$ - We assume that the social circumstances have no relevant effects on the forming of the competitors' intrinsic motivation.

$\mathrm{H} 3$ - We assume that it is possible to develop the intrinsic motivation during the sportsperson's carrier and it is not just an inherited, genetic characteristic.

Table 1. Distribution of the interviewed coaches.

\begin{tabular}{|c|c|c|c|c|c|}
\hline \multicolumn{6}{|c|}{ Distribution of the interviewed coaches $\mathrm{N}=152$} \\
\hline \multicolumn{6}{|c|}{ Sex of coaches } \\
\hline \multicolumn{2}{|c|}{$\begin{array}{c}\text { Men } \\
70\end{array}$} & & & \multicolumn{2}{|c|}{$\begin{array}{c}\text { Women } \\
82 \\
\end{array}$} \\
\hline \multicolumn{6}{|c|}{ Age of coaches } \\
\hline $\begin{array}{c}\text { 20-30 year } \\
33\end{array}$ & $\begin{array}{c}31-40 \text { year } \\
41\end{array}$ & \multicolumn{2}{|c|}{$\begin{array}{c}41-50 \text { year } \\
42\end{array}$} & $\begin{array}{c}51-60 \text { year } \\
30\end{array}$ & $\begin{array}{c}\text { Over } 60 \text { years } \\
6\end{array}$ \\
\hline \multicolumn{6}{|c|}{ Education of coaches } \\
\hline $\begin{array}{c}\text { Universit } \\
88\end{array}$ & & \multicolumn{2}{|c|}{$\begin{array}{c}\text { College } \\
55\end{array}$} & \multicolumn{2}{|c|}{$\begin{array}{c}\text { Secondary education } \\
9\end{array}$} \\
\hline \multicolumn{6}{|c|}{ Coaching qualification } \\
\hline $\begin{array}{c}\text { Masters } \\
27\end{array}$ & Gradua & oma & Gra & $\begin{array}{l}\text { certificate } \\
8\end{array}$ & $\begin{array}{l}\text { Assistant coach } \\
10 \\
\end{array}$ \\
\hline
\end{tabular}




\section{MATERIAL AND METHODS}

\section{Participants}

152 gymnastics coaches participated in the study who were of different sexes, had different academic and coaching qualifications (70 men and 82 women), and they were chosen by a stratified selection process (see Table 1).

\section{Instruments}

During the study we used the individual questionnaire as the written method, where the respondents provided their opinions on the five grades of the Likert-scale. Marking number 5 indicated full agreement; marking number 1 meant complete disagreement. The questionnaires were filled in at gymnastic halls, international training camps, during international further education courses and at visits to trainings.

The answers for the chosen variables $(50,51,52,53,54$, vv122, vv123) (see Table 2$)$ were processed by the SPSS 13.0 for Windows statistical program.

Table 2. The used seven statements in our study $N=152$.

\section{The used seven statements in our study $\mathrm{N}=152$}

vv50. The most effective motivating factor is success.

vv51. The coach does not need to worry about motivation; that is the athlete's responsibility.

vv52. Without motivation no athlete can have lasting success at a high level.

vv53. The social situation of athletes will take care of their motivation.

vv54. Motivation is genetically defined so it cannot be developed.

vv122. Money is the best motivating factor for adult gymnasts.

vv123. What is the best motivating factor for 8-10 year old gymnasts?

The Cronbach a value was -0.117 . Apart from the descriptive statistical calculations we verified the consistency of the variables by the Pearson's correlation in couples. We also performed an F-probe, and a variance analysis.

We used in conformity with parcelling the Educational level university; college; secondary school and Coaching qualifications following in our study: masters; graduate diploma; graduate certificate and assistant coach (see Table 3).

Table 3. Marked educational levels and coaching qualifications of the Coaches in our study.

\begin{tabular}{|l|l|}
\hline \multicolumn{2}{|c|}{ Marked educational levels and coaching qualifications of the Coaches in our study $\mathbf{N}=152$} \\
\hline Marked educational levels of the Coaches & $\begin{array}{l}\text { - university; } \\
\text { - college; } \\
\text { - secondary school }\end{array}$ \\
\hline Marked coaching qualification levels of the & - masters; \\
Coaches & - graduate diploma; \\
& - graduate certificate \\
& - assistant coach. \\
\hline
\end{tabular}


The coaches participating in our study had an opportunity to express their views about their gymnasts and the gymnasts' surroundings.

\section{RESULTS}

It is altogether true for the coaches featuring in the sample that according to the values of their views they are a homogeneous group. This is proven by the low value of standard deviation of their answers. This homogeneity also implies equalization of gymnastics on international levels.

The results of the Pearson's correlation study show that:

The vv50 variable correlates to the vv53 variable $(p<0.05)$.

The vv51 variable strongly correlates to the vv53 and the vv54 variables $(p<0.01)$.

The vv53 variable strongly correlates to the vv51, vv54, vv122 variables $(p<0.01)$ and correlates to the vv50 variable.

The vv54 variable strongly correlates to the vv51 and the vv53 variable $(p<0.01)$.

The vv122 variable strongly correlates to the vv53 variable (see Table 4).

Table 4. The correlation analysis of the statements in our study $N=152$.

\begin{tabular}{|c|c|c|c|c|c|c|c|c|}
\hline & & vv50 & vv51 & vv52 & vv53 & vv54 & Vv122 & Vv123 \\
\hline \multirow[t]{2}{*}{ vv50 } & $\begin{array}{l}\text { Pearson } \\
\text { Correlation }\end{array}$ & 1 & & & & & & \\
\hline & Sig. (2-tailed) & & & & & & & \\
\hline \multirow[t]{2}{*}{ vv51 } & \begin{tabular}{|l|} 
Pearson \\
Correlation
\end{tabular} & -0.029 & 1 & & & & & \\
\hline & Sig. (2-tailed) & 0.722 & & & & & & \\
\hline \multirow[t]{2}{*}{ vv52 } & \begin{tabular}{|l|} 
Pearson \\
Correlation
\end{tabular} & 0.111 & -0.073 & 1 & & & & \\
\hline & Sig. (2-tailed) & 0.174 & 0.373 & & & & & \\
\hline \multirow[t]{2}{*}{ vv53 } & $\begin{array}{l}\text { Pearson } \\
\text { Correlation }\end{array}$ & $-0.198\left(^{*}\right)$ & $0.405\left(^{* *}\right)$ & 0.009 & 1 & & & \\
\hline & Sig. (2-tailed) & 0.015 & 0.000 & 0.911 & & & & \\
\hline \multirow[t]{2}{*}{ vv54 } & $\begin{array}{l}\text { Pearson } \\
\text { Correlation }\end{array}$ & -0.064 & $0.427\left(^{* *}\right)$ & -0.132 & $0.302\left({ }^{* *}\right)$ & 1 & & \\
\hline & Sig. (2-tailed) & 0.431 & 0.000 & 0.106 & 0.000 & & & \\
\hline \multirow[t]{2}{*}{ Vv122 } & $\begin{array}{l}\text { Pearson } \\
\text { Correlation }\end{array}$ & 0.101 & -0.088 & -0.095 & $-0.229\left(^{* *}\right)$ & -0.064 & 1 & \\
\hline & Sig. (2-tailed) & 0.214 & 0.281 & 0.244 & 0.004 & 0.432 & & \\
\hline \multirow[t]{2}{*}{ Vv123 } & $\begin{array}{l}\text { Pearson } \\
\text { Correlation }\end{array}$ & 0.038 & -0.108 & 0.035 & -0.085 & -0.083 & -0.134 & 1 \\
\hline & Sig. (2-tailed) & 0.646 & 0.185 & 0.672 & 0.297 & 0.307 & 0.099 & \\
\hline
\end{tabular}


Analyses by the coaches' sex

In the analyses by the coaches' sex the scale value of statement vv50 is high, but the standard deviation is low at the same time. The value of men's mean of answers is 4.33, and the women's is 4.30 . Their views were nearly the same: that the most effective extrinsic motivation is success. Here we would like to note that for every gymnastics coach - and of course for coaches of other sports too -, success is one of the most important extrinsic motivation. Competing is the basis of every competitive sport, and so gymnastics too. The possibility of success at competitions provides further energy and drive to prepare for the challenges of the next competitions, to raise the requirement level and intrinsic motivation of the competitors.

In the case of statement vv51 coaches believe that it is the coach's task to motivate the competitor. This is shown by the received low values of the answers (men 1.77, women 1.59).

At statement vv52 men and women agree that no gymnast is able to achieve high level of performances without intrinsic motivation, which is denoted by the high mean values (men 4.64, women 4.70).

The low values of statement vv53 show that they do not agree with the statement. Higher mean values can be seen at the women's answers, which implies that women are more likely to believe that social circumstances can settle the competitors' motivation (men 2.44, women 2.85).

Representatives of neither sex agree in the case of statement vv54 that the motivational basis is genetically coded, for which reason it is not possible to develop it. This is shown by the low values of the answers (men 1.85, women 1.86). The moderate mean value of this question and the accompanying very low standard deviations (Std. 1.026) show surprisingly identical views.

Statement vv122 explores a practical phenomenon, namely that money is the most important extrinsic motivation for adult gymnasts. Mostly men coaches do not agree with the motivational power of money 2.6, while the mean value of women's answers which is 2.94 shows that they are close to the indecisive answer category. In today's sports money as a main motive is not definite, as it is proved by the mean value of the answers received from coaches featured in the sample. At the same time different international competitions (Grand Prix, World Cup) make it possible for the competitors to earn money.

For the statement vv123 regarding the intrinsic motivation of 8-10 years old gymnasts the mean value of men coaches' answers is 2.64, while women's is 2.04 . The significance level of the answers received regarding statement vv123 (compared to the other statements) is $0.029(p<0.05)$ (see Table 5).

Table 5. Significant value of the vv123 variable by Coaches' sex $N=152$.

\begin{tabular}{|c|l|c|c|c|c|c|}
\hline & & $\begin{array}{c}\text { Sum of } \\
\text { Squares }\end{array}$ & df & $\begin{array}{c}\text { Mean } \\
\text { Square }\end{array}$ & F & Sig. \\
\hline $\begin{array}{c}\text { the intrinsic motivation } \\
\text { of 8-10 years old } \\
\text { gymnasts }\end{array}$ & $\begin{array}{l}\text { Between } \\
\text { Groups }\end{array}$ & 13.0880 & 1 & 13.880 & 4.876 & 0.029 \\
\hline & Within Groups & 426.962 & 150 & 2.846 & & \\
\hline & Total & 440.842 & 151 & & & \\
\hline
\end{tabular}


Analysis by the coaches' age

At analysis adjusting for the Coaches' age we did not find significant differences among variables.

Analysis by the coaches' education

The coaches who qualified from universities believe that success is the most effective extrinsic motivation according to statement vv50. They indicated their opinion with the highest mean of answers which is 4.34.

In the case of vv51 coaches with a university degree reject what is written in the statement as their mean of answers is the lowest 1.50 . This implies that they see the forming of the extrinsic motivational basis of the competitors' as the coaches' task. This is a strongly significant difference compared to the answers of coaches with other qualifications $0.000(p<0.01)$.

Mostly coaches who graduated from colleges find intrinsic motivation important for the sake of a constant, high level result in statement vv52. Their mean of answers is 4.76 .

Again, coaches with a university degree reject the statement that social circumstances can settle the intrinsic motivation of the gymnasts (vv53). Their mean of answers is once more the lowest 2.13 and strongly significant compared to other values of answers $0.000(p<0.01)$.

Those written in vv54 are rejected mostly by coaches with a university degree their mean of answers is 1.70. It is remarkable how differently the coaches with university degrees see the realization of motivation in the cases of all three variables. The significance value of their answers is $0.007(p<0.01)$, see Table 6 .

Table 6. Significant values by Coaches' educational level $N=152$.

\begin{tabular}{|c|l|c|c|c|c|c|}
\hline \multicolumn{2}{|c|}{} & $\begin{array}{c}\text { Sum of } \\
\text { Squares }\end{array}$ & df & $\begin{array}{c}\text { Mean } \\
\text { Square }\end{array}$ & F & Sig. \\
\hline vv51 & $\begin{array}{l}\text { Between } \\
\text { Groups }\end{array}$ & 21.318 & 2 & 10.659 & 15.535 & 0.000 \\
\hline & Within Groups & 102.234 & 149 & 0.686 & & \\
\hline & Total & 123.553 & 151 & & & \\
\hline vv53 & $\begin{array}{l}\text { Between } \\
\text { Groups }\end{array}$ & 63.265 & 2 & 31.633 & 21.758 & 0.000 \\
\hline & Within Groups & 216.623 & 149 & 1.454 & & \\
\hline & Total & 279.888 & 151 & & & \\
\hline & $\begin{array}{l}\text { Between } \\
\text { Groups }\end{array}$ & 10.106 & 2 & 5.053 & 5.063 & 0.007 \\
\hline & Within Groups & 148.710 & 149 & 0.998 & & \\
\hline & Total & 158.816 & 151 & & & \\
\hline
\end{tabular}

In the case of vv122 variable all the groups show indecisiveness according to the received values. The opinion of young coaches with secondary school education reflects that they are the ones who mostly agree that money is the most important extrinsic motivation for adult gymnasts. The mean of their answers is 2.81 . 
The highest mean of answers, 2.52 was provided by coaches with university degrees for statement vv123 which studies the intrinsic and extrinsic motivations of gymnasts aged 8-10. Most of them (87 coaches) marked the experience of learning a new element as the most important intrinsic motivation.

Analysis by the coaching qualifications

In the studied sample success is the most effective intrinsic motivator - in statement vv50 - for coaches with secondary coaching education. Their mean of answers is 4.50. Assistant coaches reject statement vv51 the most, which says that the coaches do not have to motivate their gymnasts, as they have to settle it themselves. Their mean of answers is the lowest 1.20 .

All groups with different levels of coaching education agree with those written in statement vv52, which is shown by the low homogeneity of the answers (Std. 0.649). Mostly master coaches find the necessity of intrinsic motivation important and nearly all of them agree with the statement (4.96), which shows significant difference $0.042(p<0.05)$.

At statement vv54 coaches with secondary coaching education believe that it is possible to develop the intrinsic motivation and it is not just genetically coded. Their mean of answers is the lowest (4.96). This is also a significant difference compared to the views of other groups of coaches $0.037(p<0.05)$, see Table 7.

Table 7. Significant values of the vv52, vv54 variables by coaching qualifications $N=152$

\begin{tabular}{|c|c|c|c|c|c|c|}
\hline \multicolumn{7}{|c|}{ Significant values by coaching qualifications N=152 } \\
\hline & Sum of Squares & $\mathrm{df}$ & Mean Square & $\mathrm{F}$ & Sig. \\
\hline vv52 & $\begin{array}{c}\text { Between } \\
\text { Groups }\end{array}$ & 3.419 & 3 & 1.14 & 2.805 & 0.042 \\
\hline & Within Groups & 60.134 & 148 & 0.406 & & \\
\hline vv54 & Total & 63.553 & 151 & & & \\
\hline & $\begin{array}{c}\text { Between } \\
\text { Groups }\end{array}$ & 8.828 & 3 & 2.943 & 2.904 & 0.037 \\
\hline & $\begin{array}{c}\text { Within Groups } \\
\end{array}$ & 149.987 & 148 & 1.013 & & \\
\hline
\end{tabular}

Mostly master coaches find money as a primary extrinsic motivator - vv122 - the least important, which is proved by their lowest value 2.48. Basically the answers of all groups of coaches are close to the indecisive answer category by the Likert -scale.

Coaches with secondary coaching education provided the highest mean of answers 2.42 regarding the primary intrinsic motivation of gymnasts aged 8-10. Most of the coaches marked the experience of learning a new element as the primary intrinsic motivator. 


\section{DISCUSSION AND CONCLUSIONS}

Our $\mathrm{H} 1$ hypothesis - contrary to the high mean values - was not proved. It is not possible to present a significant difference compared to other variables among the coaches' opinions studied according to sex, age, academic and coaching qualification. So, we can state that the questioned coaches' opinion is that the result reached at competitions is not the most important motivation for the gymnasts. The explanation may be that during the daily training work many other - carrier aiding - extrinsic motivations are present.

The statement worded in hypothesis $\mathrm{H} 2$, that social circumstances cannot resolve the gymnasts' extrinsic motivation, was proved with a high significance level in the analyses by academic qualifications $0.000 p<$ 0.001 . The mean of answer is 2.66 . Those who agree the least with statement vv53 are the coaches with university degree; their mean of answer is 2.13 .

Our $\mathrm{H} 3$ hypothesis was expressly proved as there is a significant difference by academic and coaching qualifications, meaning that the intrinsic motivational basis of the gymnasts can be developed and it is not just a genetically coded ability. The low mean of answers of the respondents show that they do not agree with those worded in statement vv54. The mean of answer by academic qualifications is 1.86 . This shows a strong significance value $0.007(p<0.01)$.

Mostly those who have university degree reject the statement. Their mean of answers is 1.70 . Analysis by coaching qualifications (vv54) showed a significant value, $0.037(p<0.05)$.

The mean of answer was also 1.86. This analysis also shows that the gymnasts' motivational basis can be developed and it is not an inherited ability. In this case coaches with secondary coaching qualification did not agree with statement vv54, their mean of answer is 1.58 .

The answers given for the statements that were studied based on the background variables prove the homogeneity of the studied sample. There is no significant difference in the standard deviation of the answers whether they agree or disagree with the statements. The identical opinions concluded from the answers may show that the coaches coming from different countries and from all age-groups - women and men too - who featured in the sample, see the importance of motivation and the possibility to improve it identically. The experiences acquired during the daily trainings and the competitions imply similar training work. (It is another matter however, that there are differences in results reached at international competitions.)

The important conclusion of our study is that coaches have to give distinguished attention to obtaining success at trainings and at competitions too. We can come to this conclusion as the studied gymnastics coaches' opinion is that the gymnasts' motivation cannot be resolved by external social circumstances that are far from thy gymnasiums. During the educational process - whether it is scholastic or the teaching of movements - it is the teacher's and the coach's task to form a necessary state of purpose, an incentive for the better performance (Réthyné, 2003). However, the practical implementation of the study results, the elaboration on the small details is the gymnastics coaches' task. We believe that such pedagogical methods are necessary for this like the private conversations where the partial and the main goals can be appointed. 
Appraisal as the external motivation coming from the coach is a reinforcing pedagogical activity. Demonstration can be linked to it (demonstration by drawings and mainly by video films) when using the elements, exercises performed by the most successful international level gymnasts, this way the technical part of the movement learning and the external motivation can also be realized. We find gradualism very important during teaching the elements of the exercises; also the expectation that the gymnast should have the experience of success at all levels of the education. If performing the elements within relieved conditions is necessary to reach this, then this should be applied, even if it seemingly takes a longer teaching-leaning time. Practice, however shows that this kind of seemingly slower teaching of movements makes the safe performance of the learnt elements more stable.

The results of the study imply that the continuous reinforcement of the competitors' external motivations is an essential, relevant task for the coaches. They can reach it through the adequate appointing of the aims. For more effective development the genetic and the age characteristics have to be considered. For each preparation period (long-, medium-, and short-term) it is necessary to appoint aims and goals.

The appointed aim can be the learning of new elements, exercises, also the safe, high level performing of those. We can establish that the reinforcement of the gymnasts' intrinsic motivational basis greatly depends on the strength and effectiveness of the extrinsic motivation which is an integral part of the coaching work (Ryan \& Deci, 2000; Crust, 2003; Khan, 2011).

\section{REFERENCES}

1. BIRÓNÉ NE. A sportoló felkészítése pedagógiai folyamat [Preparation of athletes is a pedagogic process]. In: Biróné N. E. (szerk.) Sportpedagógia. Dialóg Campus Kiadó, Budapest-Pécs. [In Biróné N.E. (Eds.) Sport Pedagogy. Dailog Campus Publishing, Budapest-Pécs.] 2004; 122-124.

2. BOGNÁR J, GANGL J, KONCZOS CS, FÜGEDI B, GEOSITS K.B, AGÓCS A. How are quality of life and preferred values viewed by Hungarian adults? Journal of Human Sport and Exercise. 2010; 5(1):84-93.

3. COUNSILMAN JE. Competitive Swimming Manual for Coaches and Swimmers. Counsilman Co, Inc. Bloomington, Indiana. United States. 1977.

4. CRUST L. Sport Motivation: To create a positive motivational climate you need more carrot than stick. 2003, Available from http://www.pponline.co.uk/encyc/sport-motivation.htm

5. CZEIZEL E. Sors és tehetség. [Fate and talent.] Urbis könyvkiadó, Budapest. [Urbis Publishing, Budapest.] 2004; 33-37.

6. DOIL W. A sporttevékenység ösztönző szabályozásának pszichológiai szempontjai. [The psychological aspects of incentive regulation of sports activities.] In: Nádori L. (szerk.). Az edzés és versenyzés pszichológiája. Sport, Budapest. [In: Nádori L. (Eds.). Psychology of training and racing. Sport Publishing, Budapest.] 1980; 73-81.

7. FODOR L. Fejezetek a motivációkutatásból. [Chapters from motivational research.] Gondolat Kiadó, Budapest. [Gondolat Publishing, Budapest.] 2007, 187-196.

8. HAMAR P, SZILVA ZS, SOÓS I, \& DANCS H. Body culture within the EU's competence system. Journal of Human Sport and Exercise. 2011; 6(1):146-152.

9. HARASZTOSINÉ SI. A sportolók leggyakoribb viselkedészavarai. [The most common behavioural disorders of athletes.] In: Lénárt Á. (szerk.). Téthelyzetben. Sportpszichológiáról edzőknek és versenyzőknek. Országos Sportegészségügyi Intézet, Budapest. [In: Lénárt Á. (Eds.) In strained situation. Sport psychology for coaches and athletes. National Sports Health Institute Publishing, Budapest.] 2002; 47-58. 
10. JACEK G. Az igényszint dinamikája és a sportoló pszichikai készenléte. [Dynamics of aspiration level and the athlete's psychological readiness.] In Nádori L. (szerk.). Az edzés és versenyzés pszichológiája. Sport, Budapest. [In: Nádori L. (Eds.) The psychology of training and competition.] 1980; 195-207.

11. KHAN Z. Sports Achievement Motivation and Sports Competition Anxiety: A Relationship Study. Journal of Education and Practice. 2011; 2(4).

12. KOZÉKI B. A motiválás és motiváció. [To motivate and the motivation] Akadémiai Kiadó, Budapest. [Academic Publishing, Budapest.] 1980.

13. LAPPINTS Á. Tanuláspedagógia. A tanulás tanításának alapjai. [Learning Pedagogy. Fundamentals of Teaching of Learning.] Comenius Bt., Pécs. [Comenius Bt. Publishing, Pécs.] 2002; 171-174.

14. NAGY L. Azemberi motiváció. [Human Motivation.] In Bernáth L, Révész Gy. A pszichológia alapjai. Tertia Kiadó, Budapest. [In: Bernáth L, Révész Gy. Fundamentals of Psychology. Tertia Publishing, Budapest.] 2001; 201-216.

15. NAGYKÁLDI CS. A sport és a testnevelés pszichológiai alapjai. [Basics of sport and Physical Education.] Computer Arts, Budapest. [Computer Arts Publishing, Budapest.] 1998; 54-69.

16. RÉTHY E. Motiváció, tanulás, tanítás. [Motivation, learning, teaching.] Nemzeti Tankönyvkiadó, Budapest. [National Textbook Publishing, Budapest.] 2003; 75-101.

17. RÓKUSFALVY P. Az edzés és testnevelés pszichológiája. [Psychology of training and Physical Education.] Tankönyvkiadó, Budapest. [Textbook Publishing, Budapest.] 1986; 97-115.

18. RÓKUSFALVY P. Sportpszichológia. A sporttevékenység pszichológiája. [Sport psychology. Psychology of sport activities.] Sport, Budapest. [Sport Publishing, Budapest.] 1981; 62-67.

19. RUBINSTEIN SZL. Az általános pszichológia alapjai. [Fundamentals of General Psychology.] Akadémiai Kiadó, Budapest. [Academic Publishing, Budapest.] 1974; 872-884.

20. RYAN R M, DECI E. Intrinsic and extrinsic motivations: classic definitions and new directions. Contemporary Educational Psychology. 2000; 25:54-67.

21. SÉRA L. Általános pszichológia. [Genaral Psychology]. Comenius Bt., Pécs. [Comenius Publishing, Pécs.] 1988; 161-201.

22. SIMON I, FÜGEDI B, \& BOGNÁR J. Adapted physical education in the Hungarian educational system: A conceptual framework. Journal of Human Sport and Exercise. 2010; 5(3):453-461.

23. STULLER GY. Sportpszichológia. [Sport Psychology.] TFTI, Budapest. [TFTI, Budapest.] 1985; 213-215.

24. SZABÓ M. Motiváció. [Motivation]. In: Kollár K. és Szabó É. (szerk.) Pszichológia pedagógusoknak. Osiris Kiadó, Budapest. [In: Kollár K, Szabó É. (Eds.) Psychology for Teachers]. [Osiris publishing, Budapest.] 2004; 169-185. 